\title{
Criteria for Recognition of AI as a Legal Person
}

\author{
Roman Dremliuga ${ }^{1}$, Pavel Kuznetcov ${ }^{2} \&$ Alexey Mamychev ${ }^{3}$ \\ ${ }^{1}$ School of Law, Far Eastern Federal University, Vladivostok, Russia \\ ${ }^{2}$ School of Engineering, Far Eastern Federal University, Vladivostok, Russia \\ ${ }^{3}$ Moscow State Institute of International Relations, Moscow, Russia \\ Correspondence: Alexey Mamychev, Dr. Habil. in Political Science, Ph D in Legal Science, Moscow State \\ Institute of International Relations, Moscow, Russia. E-mail: mamychev@yandex.ru
}

$\begin{array}{lcc}\text { Received: July 13,2019 } & \text { Accepted: August 18, } 2019 \quad \text { Online Published: August 20, } 2019 \\ \text { doi:10.5539/jpl.v12n3p105 } & \text { URL: https://doi.org/10.5539/jpl.v12n3p105 }\end{array}$

The study was carried out with the financial support of the Russian Foundation for Basic Research in the framework of research project No. 18-29-16129

\begin{abstract}
This question of AI legal personhood is mostly theoretical today. In article we try to generalize some common ways that existing in legal theory and practice. We analyze some cases of recognition of untypical legal persons as well enacted statements in Europe and USA. Readers will not find a detailed methodology in the paper, but rather a list of criteria that is helpful to make a decision on granting legal personhood.

Practices of European Union and the United States indicate that common approaches to the legal personality of some kinds of AI are already developed. Both countries are strongly against legal personhood of intellectual war machines. Liability for any damage of misbehavior of military AI is still on competence of military officers. In case of civil application of AI there are two options. AI could be as legal person or as an agent of business relations with other legal persons. Every legal person has to be recognized as such by society. All untypical legal persons have wide recognition of society. When considering the issue of introducing a new legal person into the legal system, legislators must take into account the rights of already existing subjects. Policy makers have to analyze how such legal innovation will comply with previous legal order, first of all how it will affect the fundamental rights and freedoms of the human beings. The legal personhood of androgenic robots that can imitate human behavior regarded in paper as a good solution to minimize illegal and immoral acts committed with their involvement. It would be a factor that keep people from taking action against robots very similar to people. Authors conclude that key factors would be how society will react to a new legal person, how changing of legal rules will affect legal system and why it is necessary. At least all new untypical legal persons are recognized by society, affects of the legal system in manageable way and brings definite benefits to state and society.
\end{abstract}

Keywords: artificial intelligence, legal person, liability, robotics

\section{Introduction}

Despite intellectual robots still don't crowd on streets of cities; the question of legal personhood of AI is quiet interesting for global scientific community. This question is mostly theoretical today but it seems that we will witness the movement of this issue to a practical sphere within the next decade. We already can find a lot of video of walking robots that in some senses smarter that dogs ${ }^{1}$.

The issue of legal personhood of AI has already some practical implications. First of all, digital technologies in general and artificial intelligence in particular dramatically changed our society. Researchers reexamine the modern legal system in terms of relevance in context of last changes in society when they analyze the issue of AI as a legal person. There is a big variety of questions: how it correlates with moral rules, how it affects economy, what would be consequences and etc. Secondly, such analysis is usually based on the pros and cons of

\footnotetext{
${ }^{1}$ See for instance Boston Dynamics videos on YouTube
} 
recognition of legal personhood of other subjects ${ }^{2}$. For instance, it makes us to revise legal personhood of corporations as well as of animals and other no typical subjects ${ }^{3}$. Finally, such review makes us prepared for the rapid changes that are taking place. There is an assumption that after developing a sufficiently intelligent system it will be introduced extremely quickly due to the substantial economic benefits. It implies that society, legal and moral systems will have no time to adapt. Five years ago driverless cars that make decision by their own was a fantastic but today we have real car accidents with such cars. AI systems make finance decisions, detect offenders and produce intellectual property.

This article tries to answer the question how we should assess AI candidates on ability to be a legal person. What has to be taken into consideration? Of course, this is not a detailed methodology, but rather a list of criteria that is helpful to make a decision on granting legal personhood.

\section{Formal Aspects}

On theoretical level there are no legal barriers to grant legal personhood to autonomous machines. As concluded by a lot of authors before there are no formal obstacles to not recognize AI as a legal person ${ }^{4}$. As some authors remark "when a legal system confers legal rights and obligations on an entity, it has determined to treat that entity as though it were a person in fact. It is a kind of pretense in which legal systems can decide to engage, regardless of whether an entity really is a person". We have experience of recognition of corporations, animals, environmental features and even idols as legal persons ${ }^{6}$. Formally legal person is just a bearer of rights and duties. If any entity has rights and obligation in accordance with law, it obtains legal personhood. As a state is able to give rights and obligations to anyone and anything, it can happen at the click of a finger. The particular array of rights and duties that composes legal personhood varies with the nature of the entity. Usually such legal entities have a system of rights and duties that has own hierarchy and interconnections. For instance, corporations and human beings are legal persons that have different sets of legal rights and duties.

There are no any rules how many legal rights and duties something need to have to be considered as legal person but usually it is a right to own property and the capacity to sue and be $\operatorname{sued}^{7}$. Legal personhood of a human being is usually recognized as something natural. Because the law is the development of the human mind, it is created with taking into consideration of human abilities, qualities, weaknesses, desires and other characteristics. System of legal rules was developed during the centuries and was based on human distinctions such as feelings, intentions and consciousness. This is why often the main arguments against AI as person of law rely on lack of some vital elements of human legal personhood. As some authors define such kind of grounds: "the missing-something arguments" ${ }^{8}$.

The opponents of granting AI a legal personhood have an understandable way of thinking. AI has no critical human qualities for personhood, among them are: consciousness, feelings, intentionality, desires, interests, creativity or something else. In case if AI shows a behavior that could be an evidence of mentioned qualities, it just means that autonomous machine imitates human behavior. As some authors commented "simulation of a thing is not the thing itself"'. Similar arguments prevail in research paper as ground against legal personhood of AI system ${ }^{10}$.

\footnotetext{
${ }^{2}$ Solaiman S. M. (2017). Legal personality of robots, corporations, idols and chimpanzees: a quest for legitimacy. Artificial Intelligence and Law, 25(2).

${ }^{3}$ Bryson J. J., Diamantis M. E., Grant T.D., (2017). Of, for, and by the people: the legal lacuna of synthetic persons. Artificial Intelligence and Law. 25(3), pp. 273-291.

${ }^{4}$ Solum B., (1992). Lawrence Legal Personhood for Artificial Intelligences. North Carolina Law Review. Volume 70, Number 4; Solaiman S.M., (2017). Legal personality of robots, corporations, idols and chimpanzees: a quest for legitimacy. Artificial Intelligence and Law, 25(2).

${ }^{5}$ Bryson J.J., Diamantis M.E., Grant T.D., (2017). Of, for, and by the people: the legal lacuna of synthetic persons. Artificial Intelligence and Law. 25(3)

${ }^{6}$ Solaiman S.M., (2017). Legal personality of robots, corporations, idols and chimpanzees: a quest for legitimacy. Artificial Intelligence and Law, 25(2).

${ }^{7}$ Solum B., (1992). Lawrence Legal Personhood for Artificial Intelligences. North Carolina Law Review. Volume 70, Number 4, p. 1239.

${ }^{8}$ Ibid. p.1262.

${ }^{9}$ Ibid.

${ }^{10}$ Etzioni A., Etzioni O. (2017). Incorporating Ethics into Artificial Intelligence. Journal of Ethics, 21(4), pp. 403-418; Asaro P. (2007). Robots and responsibility from a legal perspective. The IEEE conference on robotics and automation, http://www.peterasaro.org/writing/ASARO\%20Legal\%20Perspective.pdf; Danaher J. (2017). The rise of the robots and the crisis of moral patience. AI \& Society. pp. 1-8. https://link.springer.com/content/pdf/10.1007\%2Fs00146-017-0773-9.pdf.
} 
Supporters of the empowerment of the AI systems have other bundle arguments. They most often appeal to legal practice related with corporations, animals or children and mentally incompetent people ${ }^{11}$. Any humans and corporations are commonly recognized legal persons. They are capable of holding rights and duties. Of sure modern legal systems limit their rights and duties. As for animals they are mostly not acknowledged as bearers of rights and duties ${ }^{12}$.

Legal personality of AI is not only a scientific issue; this problem is discussed at the highest political level. It is obvious that the leaders in this area are developed countries with a high level of digitalization. Among leaders in discussion of potential legal status of AI are European Union and USA.

European Union. For instance, in recommendations to the Commission on Civil Law Rules on Robotics for European Parliament the question of the legal personhood of AI is raised. The act states that "whereas, ultimately, robots' autonomy raises the question of their nature in the light of the existing legal categories - of whether they should be regarded as natural persons, legal persons, animals or objects - or whether a new category should be created, with its own specific features and implications as regards the attribution of rights and duties, including liability for damage" ${ }^{\prime 13}$. This act could not be considered as a legally binding document because it does not create any formal duties or obligations. The mention of legal status of AI in high level political manifest implies that an issue of legal personhood of sophisticated machines is not just a topic of a science fiction and research.

In Strategic Plan 2016-2020 European Commission proclaims that it «will explore the legal frameworks for autonomous systems, in particular safety and liability rules and the legal conditions to allow large scale testing in real life environments» ${ }^{14}$. It does not directly mention $\mathrm{AI}$ ' personhood issue, but fast development of autonomous system implies attention to this question.

In 2017 European parliament in its resolution "Civil Law Rules on Robotics" stated that in the long run an autonomous robot could be considered as an electronic person. Of sure it is not a statement but agenda of future development but as proclaimed in provision $59 \mathrm{~F}$ of resolution "at least the most sophisticated autonomous robots could be established as having the status of electronic persons responsible for making good any damage they may cause, and possibly applying electronic personality to cases where robots make autonomous decisions or otherwise interact with third parties independently"15. The assertion implies that EU parliament does not deny the possibility that artificial intelligence may become an independent subject of civil law.

In 2018, the EU Commission released «Artificial Intelligence: a European approach to boost investment and set ethical guidelines» (Doc. IP/18/3362). In press release EU commission proclaim that «Artificial intelligence (AI) is not science fiction; it is already part of our everyday lives». The document does not formulate that issue of legal personhood of AI in priority but it states that «artificial intelligence may raise new ethical and legal questions, related to liability or potentially biased decision-making» ${ }^{16}$.

Another document where we can find expression of attitude on legal personhood in Europe is the Statement on «Artificial Intelligence, Robotics and 'Autonomous' Systems» developed European Group on Ethics in Science and New Technologies ${ }^{17}$. This manuscript could not be regarded even as political because it does not express official position. Nevertheless staff of the European Commission services participated in the preparation of the statement, and it could be regarded at least as closest expert opinion to official view.

\footnotetext{
${ }^{11}$ Koops B-J, Hildebrandt M, Jaquet-Chiffelle D-O, (2010). Bridging the accountability gap: rights for new entities in the information society. Minnesota Journal of Law, Science \& Technology, Vol. 11, № 2. pp. 497-561.

${ }^{12}$ Solaiman S.M., (2017). Legal personality of robots, corporations, idols and chimpanzees: a quest for legitimacy. Artificial Intelligence and Law, 25(2).

${ }^{13}$ Draft Report of Committee on Legal Affairs (Rapporteur: Mady Delvaux) with recommendations to the Commission on Civil Law Rules $\begin{array}{ll}\text { on } & \text { Robotics } \\ \text { (2015/2103(INL)), }\end{array}$ http://www.europarl.europa.eu/sides/getDoc.do?pubRef=-\%2F\%2FEP\%2F\%2FNONSGML\%20COMPARL\%20PE-582.443\%2001\%20DO C\%20PDF\%20V0\%2F\%2FEN

14 Communications Networks, Content and Technology - $\quad$ strategic plan 2016-2020. https://ec.europa.eu/info/sites/info/files/strategic-plan-2016-2020-dg-cnect_may2016_en.pdf

15 Civil Law $\quad$ Rules on $\quad$ Robotics $\quad$ - $\quad$ European $\quad$ Parliament.

http://www.europarl.europa.eu/sides/getDoc.do?type=TA\&reference=P8-TA-2017-0051\&language=EN\#BKMD-12

${ }^{16}$ Artificial intelligence: Commission outlines a European approach to boost investment and set ethical guidelines, European Commission, April 25, 2018, http://europa.eu/rapid/press-release_IP-18-3362_en.htm

17 Statement on "Artificial Intelligence, Robotics and 'Autonomous' Systems», http://ec.europa.eu/research/ege/pdf/ege_ai_statement_2018.pdf
} 
The text of the mentioned publication makes it clear that only a person can be a subject of responsibility and rights and cannot shift it to autonomous machines. As proclaimed there «the ability and willingness to take and attribute moral responsibility is an integral part of the conception of the person on which all our moral, social and legal institutions are based ... Moral responsibility, in whatever sense, cannot be allocated or shifted to 'autonomous' technology». It implies that moral responsibility could not be characteristic of AI. But it is a necessary property of moral and legal personhood, thus AI could not be regarded as legal person.

In case of Lethal Autonomous Weapons Systems (LAWS) opinion of experts is even more obvious. As it proclaimed in the statement "humans - and not computers and their algorithms - should ultimately remain in control, and thus be morally responsible" ${ }^{\prime 18}$.

It is hardly to understand what the official position of EU on potential legal personhood of AI from mentioned sources. Does European Union for or against the legal personality of artificial intelligence? At least one conclusion could be done. EU considers the legal personality of AI only in the sphere of civil law. In accordance with analysis of documents mentioned above AI could be rather an independent actor of business transactions than guilty of offence.

The United States. Another act cited in papers ${ }^{19}$ is Law of War Manual of the United States Department of Defense $^{20}$. In provision 6.5.9.3 "Law of War Obligations of Distinction and Proportionality Apply to Persons rather than the Weapons Themselves" every reader is able to find opinion on legal personhood of AI machines used in war. The article of manual proclaims that «the law of war does not require weapons to make legal determinations, even if the weapon (e.g., through computers, software, and sensors) may be characterized as capable of making factual determinations, such as whether to fire the weapon or to select and engage a target». Bryson regards it as an indicator that "robotic weapons are never responsible legal agents" ${ }^{21}$ but the Manual is just official recommendation how military officers have to interpret International Humanitarian Law ${ }^{22}$. Like any interpretation of international law, it can evolve over time and, principally, "does not require" does not imply "could not" or that it has to be ban ${ }^{23}$.

Report issued in 2016 by the NSTC Committee on Technology "National Artificial Intelligence Research and Development Strategic Plan" and published by the Executive Office of the President defines key measures to maximize the benefits of AI technology. Among other things suggested in report there is a proposal to develop robots that could follow ethical and legal rules. As proclaimed in "Strategy 3: Understand and Address the Ethical, Legal, and Societal Implications" subdivision "Building ethical AI" of report "within the limits of what is technologically feasible, therefore, researchers must strive to develop algorithms and architectures that are verifiably consistent with, or conform to, existing laws, social norms and ethics-clearly a very challenging task ${ }^{24}$. It does not mean that report text proposes to recognize AI legal personhood, but at least we will get autonomous machine that is able to follow ethical and legal rules i.e. to exercise moral and legal rights and obligations.

Practices of European Union and the United States indicate that common approaches to the legal personality of some kinds of AI are already developed. Both countries are strongly against legal personhood of intellectual war machines. Liability for any damage of misbehavior of military AI is still on military officers. In case of civil application of AI there are two options. AI could be as legal person or as an agent of business relations with

\footnotetext{
${ }^{18}$ Ibid.

${ }^{19}$ Bryson J.J., Diamantis M.E., Grant T.D., (2017). Of, for, and by the people: the legal lacuna of synthetic persons. Artificial Intelligence and Law. 25(3)

20 U.S. Department of Defense, Law of War Manual, 6.5.9.3 (2015), http://www.defense.gov/Portals/1/Documents/pubs/Law-of-War-Manual-June-2015.pdf

${ }^{21}$ Bryson J.J., Diamantis M.E., Grant T.D., (2017). Of, for, and by the people: the legal lacuna of synthetic persons. Artificial Intelligence and Law. 25(3). P. 285

${ }^{22}$ This manual reflects many years of labor and expertise, on the part of civilian and military lawyers from every Military Service. It reflects the experience of this Department in applying the law of war in actual military operations, and it will help us remember the hard learned lessons from the past. Understanding our duties imposed by the law of war and our rights under it is essential to our service in the nation's defense.

${ }^{23}$ Arato J., (2010). Subsequent Practice and Evaluative Interpretation: Techniques of Treaty Interpretation over Time and Their Diverse Consequences. The Law and Practice of International Courts and Tribunals, 9, pp. 443-494; Bjorge Eirik I., (2011). International Court of Justice, Case concerning the dispute regarding navigational and related rights (Costa Rica v Nicaragua) judgment of 13 July 2009. International and Comparative Law Quarterly, 60, pp. 271-279.

${ }^{24}$ Artificial intelligence: Commission outlines a European approach to boost investment and set ethical guidelines, European Commission, April 25, 2018, http://europa.eu/rapid/press-release_IP-18-3362_en.htm.
} 
other legal persons. Both states allow possibility that AI becomes a full-right participant in civil law relations. It implies that autonomous machine will be able to conclude deals, sell something, and provide services by its own. But it seems that in case of criminal law such scenario even in future is impossible.

Possible Arguments against. Analysis of political and theoretical approaches to the problem of recognition of AI as a subject of law shows that at the moment there is no agreement on this issue. As we offer in introduction it would be reasonable to answer the question of legal personality from the point of view of generally accepted arguments against. The paper does not suggest to answer the question whether should states recognize AI as legal person or not, but it provides what have to be taking into consideration.

Social recognition. There is no doubt that every legal person has to be recognized as such by society. All untypical legal persons have wide recognition of society. For instance, Hindu idols in India in accordance with belief of people have "peculiar desires and a will of its own which must be respected" ${ }^{25}$. Maori people of New Zealand recognized national park and an important river as very significant part of their life and these environmental features were acknowledged as legal persons by the state ${ }^{26}$. New Zealand Permanent commission that named Waitangi Tribunal defined that local community treats local river Whanganui River as "a whole and indivisible entity", "a living being with its own mauri [a life-force and personality of their own] and spiritual integrity" ${ }^{27}$. As many indigenous cultures perceive the world as a living organism where other important entities exist beside human beings, environmental features are often recognized as legal persons ${ }^{28}$.

Cases mentioned above imply that a fictional legal person has to be treated at least as natural legal person (human being). For instance, in litigation Salim vs State of Utarakhand (state of India) the High Court of the area proclaimed that "Ganga and Yamuna Rivers and all their (115) tributaries and streams.... are juristic persons with all the corresponding rights duties and liabilities of a living person" ${ }^{, 29}$. As some authors claim modern sociocultural anthropology research demonstrates that pets are very close to get legal and social personhood ${ }^{30}$. Because pets are usually recognized like members of family and treated this way, they could obtain legal personhood soon.

If we draw an analogy with environmental features and some potential legal persons, it is necessary for AI to have respect from human. Even Famous Turing test has no legal meaning but it indicates that people tend to measure the personhood of a machine with the ability to be recognized by a person. This implies that people consider them as equal participants in social relations. For instance, it was shown in Hollywood movie "Her" 31 where a lonely man fell in love with intellectual operating system. He respected her advice and attitude, and felt her occasional disconnection like death of a real human being.

Social recognition for untypical legal persons (every except humans beings and corporations) is also critical in terms of practical protection of legal interests. An Idol could not come to court by his own, on practice it represented by human beings who are lawfully entitled to operate them with all the powers. As some authors comment "When an idol's legal personality comes to its power of will, a question may emerge as to how to ascertain such a will. Perhaps the best answer would be that whatever the relevant law regards as its power of will, giving due consideration to the interests of the worshipers as well as social interests in materializing the wishes of pious founders, will be the idol's will, ${ }^{\prime 2}$.

For autonomous machine recognition of potential representatives would be also crucial. As AI is not able to have intentions and desires in terms of human understanding of these terms, it is very important to have proxy who

\footnotetext{
${ }^{25}$ Solaiman S.M., (2017). Legal personality of robots, corporations, idols and chimpanzees: a quest for legitimacy. Artificial Intelligence and Law, 25(2). P. 170.

${ }^{26}$ Athens, A.K., (2018). An indivisible and living whole: Do we value nature enough to grant it personhood? Ecology Law Quarterly, 45(2), pp. 187-226. The River Whanganui https:/forms.justice.govt.nz/search/Documents/WT/wt_DOC_68450539/Whanganui\%20River\%20Report\%201999.pdf

${ }^{28}$ Fraundorfer, M. (2018). The Rediscovery of Indigenous Thought in the Modern Legal System: The Case of the Great Apes. Global Policy. 9(1), pp. 17-25.

${ }^{29}$ Salim v State of Utarakhand (2017) in Studley, J., Bleisch, W.V. (2018). Juristic personhood for sacred natural sites: A potential means for protecting nature. Parks, 24(1),

${ }^{30}$ Rock, M., Degeling, C., (2013). Public Health Ethics and a Status for Pets as Person-Things: Revisiting the Place of Animals in Urbanized Societies. Journal of Bioethical Inquiry, 10(4), pp. 485-495.

${ }^{31}$ See description of movie: https://www.imdb.com/title/tt1798709/

32 Duff P.W. (1929). The personality of an idol. Cambridge Law Journal. 3(1). pp. 42-48.
} 
represents robot's will. Of note, previous practice of fictional personhood cases shew that mostly something was recognized for the benefit of human beings or in accordance with some people's view.

Mentioned examples of environmental objects recognition as legal persons demonstrate that sometimes it is enough to be recognized by small minority. It is possible due to legal pluralism when legal system take into account historical, cultural, and contemporary factors ${ }^{33}$. May be it would be enough if Way of the Future church that "believes the creation of "super intelligence" 34 had a lot of followers.

Described above cases do not imply that social recognition is necessary or enough for legal personhood, but it means that the lack of social recognition is a crucial obstacle for untypical legal persons. Modern examples of new legal person's recognition indicate that such shift is based on changing cultural norms ${ }^{35}$. State would be difficult to justify a new legal person in case it would not recognized by whole society or some group of society.

\section{Legal System}

Law is a system of legal norms ${ }^{36}$. Systematicity of law implies that norms and rules are interrelated and "no two contradictory norms can be simultaneously valid"37. Granting of legal personhood to intellectual computer systems is valid only if a new legal regime is not in a serious conflict with legal norms that exist before. It implies that we have to test how obligation to respect rights of AI would affect rights of other legal persons. The obvious question how it restricts rights of a human being.

Everybody who watches video from Boston dynamics robot tests where researchers kick, push and do other bad things with autonomous machines ${ }^{38}$, understands that such behavior is impermissible in respect of human. In accordance with the law nobody could kick other human being. Legal personhood implies that person is protected by law from encroachment. Other legal persons have to respect the rights of a recognized legal person and refrain from violating them. In other words, the rights of new legal persons create the obligation to respect these rights of other legal persons recognized before. And recognition of AI or a robot with AI as a legal person probably means the engineers will not be able to kick it or test it again.

Recognition of environmental feature as a legal person means that it has rights and others have new obligation not violate these rights. For instance, Article 71 of Ecuador Constitution states that "Nature, or Pacha Mama, where life is reproduced and occurs, has the right to integral respect for its existence and for the maintenance and regeneration of its life cycles, structure, functions and evolutionary processes ${ }^{\prime 39}$. Legislation of Ecuador defines how to enforce and interpret these rights. In accordance with Ecuador law all natural persons and legal entities, the state has obligation to refrain from violating the rights of the nature as a person of law.

Conflict between rights of different kind of legal entities could not be instantly resolved. Usually it takes a lot of time for forming of legal practice and sometimes fights for rights. Peoples during a long time were suppressed by corporations; they work hard without any rights except modest salary. As we all know the balance between rights of natural persons and corporation is mostly shifted in favor of people. Today, people are guaranteed a lot of rights that create a lot of corporate duties. Current legal regime is a result of long evolution.

The other side of systematicity of law is an impact of a new legal norm on other norms too, and on their relations with one another ${ }^{40}$. A new rule will inevitably affect the application, interpretation or conflict with other norms. Enacting of a new legal person would be like a storm in legal system that affects a lot of institutions, principals and etc. To make a decision on the empowerment of AI with legal personality it is necessary to understand that such a decision will change the legal system as a whole.

The basic purpose of human legal systems is to further the material interests of the legal persons and interests of people are usually is in the center. Some most vital human rights are outwardly national legal system and must

\footnotetext{
${ }^{33}$ Charpleix, L., (2018). The Whanganui River as Te Awa Tupua: Place-based law in a legally pluralistic society. Geographical Journal, 184(1), pp. 19-30.

${ }^{34}$ See: http://www.wayofthefuture.church/

${ }_{35}$ Athens, A.K., (2018). An indivisible and living whole: Do we value nature enough to grant it personhood? Ecology Law Quarterly, 45(2), p. 187.

${ }^{36}$ Kelsen Hans. (2008). Pure Theory of Law. Publisher: Clark, N.J.: The Lawbook Exchange, Edition: Firth printing. p. 31.

${ }^{37}$ Bulygin Eugenio. (2015). Kelsen on the Completeness and Consistency of Law in Essays in Legal Philosophy, Oxford Scholarship Online. pp. 337-355.

${ }^{38}$ Input "Boston dynamics" on YouTube.

${ }^{39}$ English translation http://pdba.georgetown.edu/Constitutions/Ecuador/english08.html

${ }^{40}$ Waldron Jeremy, (2000). Transcendental Nonsense and System in the Law. Columbia Law Review. Vol 100, 16, pp. 16-53. http://emoglen.law.columbia.edu/persp/waldron-cohen.pdf.
} 
be respected regardless of the provisions of national law. As practice indicates human rights could not be affected, conversely, volume of rights given to people has to be increased with the lapse of time. In other words, when considering the issue of introducing a new legal person into the legal system, we must take into account the rights of already existing subjects. Policy makers have to analyze how such legal innovation will comply with previous legal order, first of all how it will affect the fundamental rights and freedoms of the human beings.

\section{Question of Necessity}

Probably the main question when we decide to give legal personhood to some autonomous computer system would be why we are going to do it. What would be preferences for society in case of recognition?

For instance, the recognition of corporations as legal persons has obvious economic effect. Corporations are artifacts created by human beings to serve particular purposes. Corporation is able to have its own property, conclude transactions, hire staff etc. The legal entity acts as a whole and is able to file lawsuits and be a lawsuit defendant. All modern economy exists due to this legal fiction. When scholars analyze legal personhood of corporations they usually do not discuss dignity, consciousness, and intrinsic worth. Usually arguments are in sphere of "efficiency, financial transparency, accountability, and the like"41. Social and economic effects are taken into consideration.

The similar situation is with legal recognition of environmental features or the entire ecosystem. No sensible researcher or policy maker would evaluate the legal personality of such objects in terms of their human characteristics or qualities. Legal personhood of such object could be based on benefits of local societies, society or humanity as a whole ${ }^{42}$. Sometimes it has high political, social and economy meaning. For instance, as some authors fairly comment "by transforming a former national park and an economically important river from property to legal persons under the guardianship of the interested Māori tribe, the New Zealand Crown government eschewed rigidity in order to meet their treaty obligations while also safeguarding the best interest of each natural feature as an ecological system"43.

What could be a reason for AI personhood recognition? It is hard to imagine any rational arguments but we try to do. We have no moral obligations to recognize AI as legal person because it does not feel pain. We could not use the same grounds that applied by animal rights advocates ${ }^{44}$.

Probably question is not in the sphere of our moral duties. Some commentators interpret illegal actions with objects similar to human being both externally and behaviorally as immoral ${ }^{45}$. Technology already allows to developing AI robots that resemble real people. For instance sex robot harmony does not "only look like women but have a similar feel, and they react like real people in conversations too"46. Some users of this doll point out that an intimate relationship with her is very similar to a real woman ${ }^{47}$. In accordance with modern law in majority of states rape of AI sex doll is not a crime and it is transparent how it would be assessed from moral point of view.

There are some cases indicate that virtual illegal or immoral acts could be regarded as immoral. For instance, game «Rape day» where player could sexually assault and murder women is banned by gaming platform «Steam ${ }^{48}$. Some researchers insist that demonstration of illegal scenes or participation in illegal activity even

\footnotetext{
${ }^{41}$ Pagallo, U. (2018). Vital, Sophia, and Co.-The quest for the legal personhood of robots. Information (Switzerland), 9(9). P. 230.

${ }^{42}$ Studley, J., Bleisch, W.V. (2018). Juristic personhood for sacred natural sites: A potential means for protecting nature. Parks, 24(1), pp. 81-96.

${ }^{43}$ Athens, A.K., (2018). An indivisible and living whole: Do we value nature enough to grant it personhood? Ecology Law Quarterly, 45(2), p. 187.

${ }^{44}$ Chen, J., Burgess, P. (2019). The boundaries of legal personhood: how spontaneous intelligence can problematise differences between humans, artificial intelligence, companies and animals. Artificial Intelligence and Law, 27(1), pp. 73-92.

${ }^{45}$ Strikwerda L. (2015). Present and Future Instances of Virtual Rape in Light of Three Categories of Legal Philosophical Theories on Rape. Philosophy and Technology, 28(4), pp. 491-510.

46 My 4 fake conversation with a $\quad$ sex robot. https://www.news.com.au/lifestyle/relationships/sex/my-fake-conversation-with-a-sex-robot/news-story/ab7b4226e88d9b34a783748d67d24 350.

47 Sex robot: World's first Harmony first owner lays bare life with cyborg he claims is "THE FUTURE" https://www.dailystar.co.uk/news/latest-news/719480/sex-robot-doll-harmony-first-owner-realdoll-video-realbotix-2018-brick-dollbanger; The race to build the world's first sex robot https:/www.theguardian.com/technology/2017/apr/27/race-to-build-world-first-sex-robot;

48 'Rape Day' computer game where players sexually assault and murder women amidst scenes of necrophilia and incest sparks outrage https://www.dailymail.co.uk/news/article-6772707/Rape-Day-computer-game-players-sexually-assault-murder-women-sparks-outrage.html.
} 
with "fake" human beings could be regarded as unlawful and (or) immoral. As examples, they cite rape, child porn or cases of pedophilia in virtual reality ${ }^{49}$.

Some domestic law also reflects that any visual depiction of any sexually explicit conduct could be regarded as crime $^{50}$. As some authors fairly underlines "it does not matter if the material contained images of actual children" ${ }^{, 51}$. At the same time it is possible to produce realistic copy of minor, which would be used in different ways. How would be treated production of pornography or life theaters with such artificial participants? Because they are very similar to real minor it has to be regarded at least as crimes in virtual reality.

Sex industry is a leader of androgenic intellectual robot development. Last researches prove that "sexualized portrayals of women lead to objectification and corresponding dehumanization of women, which leads to the denigration of rape victims and the acceptance of rape myths" $" 52$. Despite there is still no evidence that rape of robot that looks like a real woman could lead to even strongest justification of rape in society, such suggestion is very logical ${ }^{53}$.

It can be concluded that the legal personhood of androgenic robots that can imitate human behavior would be a good solution to minimize illegal and immoral acts committed with their involvement. It would be a factor that keep people from taking action against robots very similar to people. Such treatment of AI does not imply that we have moral obligation to give rights to androgenic robots but it means that we should follow commonly recognized moral and legal rules with respect to subjects to the extent of mixing similar to us.

\section{Conclusion}

It seems that there is no definite algorithm or guideline to detect should or should not grant legal personhood to AI. So the main result of this essay is absence of an outcome. But in another way we found places where policy makers could find answers. For some kinds of AI we have definite decisions, for instances for autonomous weapon. The possibility of recognition of killing machine with AI as a legal person is totally denied. For some other kinds of intellectual machine, for instance androgenic intellectual robots, we just have blurred possible grounds.

Moreover there is no combined concept of AI that could be once tested. Humankind has to decide it case by case. We suggest that key factors would be how society will react to a new legal person, how changing of legal rules will affect legal system and why it is necessary. At least all new untypical legal persons are recognized by society, affects of legal system in manageable way and brings definite benefits to state and society.

\section{Copyrights}

Copyright for this article is retained by the author(s), with first publication rights granted to the journal.

This is an open-access article distributed under the terms and conditions of the Creative Commons Attribution license (http://creativecommons.org/licenses/by/4.0/).

\footnotetext{
${ }^{49}$ Strikwerda L. (2015). Present and Future Instances of Virtual Rape in Light of Three Categories of Legal Philosophical Theories on Rape. Philosophy and Technology, 28(4), p. 570, 572, 574-575.

5018 U.S. Code $\S 2251$. Sexual exploitation of children

${ }^{51}$ Strikwerda L. (2015). Present and Future Instances of Virtual Rape in Light of Three Categories of Legal Philosophical Theories on Rape. Philosophy and Technology, 28(4), p.574.

${ }^{52}$ Fox, J., Ralston, R.A., Cooper, C.K., Jones, K.A. (2015). Sexualized Avatars Lead to Women's Self-Objectification and Acceptance of Rape Myths. Psychology of Women Quarterly, 39(3), p. 351.

${ }^{53}$ Baranov P., Mamychev A., Mordovtsev A., Danilyan O., Dzeban A. (2018). Doctrinal-legal and ethical problems of developing and applying robotic technologies and artificial intelligence systems (using autonomous unmanned underwater vehicles). National Academy of Managerial Staff of Culture and Arts Herald. № 2. p. 465 - 472.
} 